DOI: https://doi.org/10.32839/2304-5809/2020-78.1-11

UDC 81'33

Komarnytska Oksana

Bohdan Khmelnytskyi National Academy of the State Border Guard Service of Ukraine

\title{
MODELS OF AUTOMATED EVALUATION OF HUMAN TRANSLATION QUALITY
}

Summary. The means of applied and computational linguistics, providing the users with the specialized tools enabling adequate and efficient comparison of the source-language text, target-language text and model-text have been described in the article. The research conducted made it possible to accomplish analysis of the existing models of human translation quality automated evaluation system and suggest the innovative way of developing the new intellectual automated linguistic system of human translation quality assessment, based on conducting morphological, syntactical, semantic, and pragmatic text analysis, applying improved Levenstein distance metric, latent semantic analysis and models of artificial intelligence.

Keywords: translation quality assessment, morphological analysis, syntactic analysis, semantic analysis, pragmatic analysis, automated evaluation system.

Комарницька O.I. Національна академія Державної прикордонної служби України імені Богдана Хмельницького

\section{МОДЕЛІ АВТОМАТИЗОВАНОЇ ОЦІНКИ ЯКОСТІ ПЕРЕКЛАДУ, ВИКОНАНОГО ЛЮДИНОЮ}

\begin{abstract}
Анотація. Статтю присвячено дослідженню засобів автоматичної оцінки якості перекладів, виконаних людиною, оскільки аналізована царина лінгвістичної науки залишається досить малодослідженою на відміну від оцінки якості машинного перекладу. Автор статті аналізуе засоби прикладної та комп'ютерної лінгвістики, що пропонують користувачам спеціалізовані інструменти, які дозволяють адекватно й ефективно порівнювати текст-джерело, текст-переклад та текст-зразок. У статті розглянуто декілька найбільш поширених програмних продуктів, спеціально розроблених для оцінки якості перекладу (ТQА). З'ясовано, що такі інструменти використовують низку критеріїв перевірки і дозволяють користувачеві встановлювати власні налаштування, що зменшуе кількість випадкових помилок, але дозволяе виявляти більш вагомі; крім того, вони здатні одночасно обробляти велику кількість фрайлів, які можна завантажити у відповідні теки. У випадку, якщо фрайли належать до одного проекту, усі вони можуть бути піддані аналізові та оцінці за однаковими критеріями перевірки й оброблені всі одразу. Проте, наявні програмні засоби мають низку недоліків, шляхи усунення яких запропоновані автором наукової статті. Проведене дослідження дозволило здійснити аналіз існуючих моделей автоматизованої системи оцінювання якості перекладу людини та запропонувати інноваційний спосіб розробки нової інтелектуальної автоматизованої лінгвістичної системи оцінки якості перекладу людини на основі проведення автоматичного морфологічного, синтаксичного, семантичного та прагматичного аналізу текста, застосовуючи вдосконалену метрику Левенштайна, метод латентно-семантичного аналізу тексту та моделі штучного інтелекту. Результати проведеного дослідження можуть бути використані для оптимізації діяльності перекладачів-практиків та в освітньому процесі в рамках підготовки фахівців у галузі перекладу.
\end{abstract}

Ключові слова: оцінка якості перекладу, морфологічний аналіз, синтаксичний аналіз, семантичний аналіз, прагматичний аналіз, автоматизована система оцінювання.

Droblem statement. Worldwide globalization process leads to ever-growing amounts of texts to be translated into different languages. Though quality of their translation is not always high enough. No matter how experienced translator is, and no matter how careful the editor who checks his work is, it hardly guarantees the complete absence of translation errors. After all, high-quality translation aims at not just to accurate conveying the meaning of the original but also complying with the rules of spelling, punctuation and grammar. In addition, to achieve impeccable quality, such things as the same translation of specialized terminology throughout the texts, unified spelling of words when there are several valid variants, adherence to the rules of typography, writing numbers in accordance with the rules of a particular language, and much more. Therefore, in order to eliminate the errors caused by the imperfection of human memory and attention, the verification process should be automated.
As it is well known, automatic text checking can be performed by MS Word or, for example, by an Open Office editor, into which additional validation macros can be imported. However, they do not compare the translation with the original. Here comes the means of applied linguistics, providing users with the tools enabling adequate and efficient comparison of the source-language text, target-language text and model-text.

Recent research and publications. Problems of analysis and evaluation of translation quality have been widely researched since the processes of informatization and globalization seized the reins of power in the world. Matters of translation quality assessment were studied by House J., Scriven M., Williams M., Komissarov V., Fedorov A., Naida Yu., Balendr A., Bloshcynskyi I. [1; 4; 8; 12]. In particular, special attention is focused nowadays on the problems of machine translation quality evaluation, as there is a wide range of commonly used machine translation tools. This field of linguistics has been 
investigated by Barkhudarov L., Vinogradov B., Kade O., Marchuk Yu., Gudmanian A., Mishchenko A., Stakhmych Yu.

Translation quality assessment has long been the focus of scientific attention but there are still no 'generally accepted objective criteria for evaluating the quality of translations' [12]. But the area of automated evaluation methods of human translation quality has not been researched enough, and it, consequently, is the subject of this article.

The purpose of the article. This study aims at analyzing the existing and suggesting the new methods and models of human translation quality automated evaluation system.

Presentation of the main material. Modern computational linguistics accomplishes a wide range of tasks to improve the computer-aided modeling of human language and communication competence. Nowadays there are several popular software products specifically designed for the purpose of translation quality assessment (TQA). Such tools use a number of criteria for validation and allow the user to set their own settings, which reduces the number of false errors, but allows more real ones to be detected. In addition, they are able to handle a large number of files at one time, which can be downloaded into entire folders. If the files belong to the same project, all of them can be set to the same validation criteria and processed all at once. Let us briefly have a look at some of the most widely used TQA programms.

XBench. Firstly, it is a powerful search tool for translating words or expressions of certain types. In fact, it is a high-tech concordance. Special codes (wildcards) are used for this purpose, as well as a formal language for searching for the elements of the text, called "regular expressions". The program provides a list of the most current expressions, in addition to which the user can create his/her own ones. Secondly, the program detects translation errors using its search tools. Terminological bases and glossaries are marked as sources of terms, that is, objects to look for. Xbench comes with some useful predefined quality checks for completeness, consistency, numbers, tags, key terms, and so on. But if you need more, you can also create your own personal checklists to make sure that your translations are perfect [13].

$Q A$ Distiller. This is a special program for finding translation errors. It allows loading several bilingual files or even folders with files. For example, glossaries in XML format are loaded to check the terminology. Automatically it detects common errors like double spaces, missing brackets, and wrong number formats, jumping directly to the location of the error in the file format's proprietary editor or the internal X-Editor. It creates different profiles, personal checks and reduces the noise from false positives using regular expressions. A major drawback of this program is that it does not provide spell check and the tag match with the source text [14].

Verifika is a software tool that helps to locate and resolve formal errors in bilingual translation files and translation memories. It detects formatting, consistency, terminology, grammar and spelling errors in the target language. All detected errors are included in a report which allows to conveniently correct them with no external software tool (such as TagEditor) required. Verifika features an internal editor for reviewing and amending translations. For many error types, Verifika also offers an auto-correction feature. Its powerful search feature allows you to perform further corrections if necessary. The error report can only be saved as an Excel spreadsheet, which does not allow you to continue correcting the errors found during the next session [15].

Taking into account all the drawbacks of the existing TQA tools it is necessary to create complex linguistic models, adapted to formal representation in systems of translation assessment, free from the flaws mentioned above.

Perspective TQA systems should be based on such linguistic tools capable of processing natural-language texts, while performing a number of quite complex linguistically meaningful operations of morphological, syntactic, semantic, pragmatic analysis of the text and focused mainly on identifying its meaningful characteristics.

So, in order to automate the process of TQA, it is necessary to develop an effective method of comparing the translated text with the model text. This method should be used in formulating a conceptual model of the corresponding system, which involves the creation of theoretical foundations, the development of the general scheme of the system and the structure of its individual components, as well as the relationships between them, the development of the necessary elements of the system (linguistic, algorithmic, mathematical, software, informational, organizational, etc.).

The development of the functional structure of the TQA linguistic system modules is of great importance of the study. The task of the linguistic system in the stages of morphological, syntactic, semantic and pragmatic analysis is to reduce the variety of possible meanings of words and their relationships in the context of unambiguous interpretation of the input information relevant to a specific subject area. The main role in sentence analysis is played by an integrated database containing information about morphology, syntax, semantics and pragmatics of words.

Within the process of translation, the translator can make a mistake in spelling, incorrectly construct sentences, use non-standard abbreviations etc. The process of analyzing the information should include several steps, during which these errors will be eliminated with the help of string metric for measuring the difference between two sequences called 'Levenshtein distance'.

The result of the morphological analysis of the translated text is a set of word forms, each of which is determined by its linguistic identity and such grammatical characteristics, which establish the syntagmatic relations between words necessary for the next stage of syntactic analysis. As a result of the lemmatization process, every word in the input information is distinguished by the lemmas, which are further processed by latent-semantic analysis. An improved version of the Levenstein metric was used in the morphological analysis module to identify and correct misspelled words (insertion, replacement, skip, transposition). The advantage of the method is that it allows limiting the number of possible errors in the text [7]. 
The results of the morphological analysis in the form of a set of lexical and grammatical characteristics of word forms come to the input of the work of the parser, the purpose of which is to build a syntactic structure of sentences of the text, which involves establishing the functional role of each token in the sentence, establishing and analyzing the relations between them.

The most complex and problematic is the procedure of semantic analysis of incoming text information, the main task of which is to extract semantics from a text and to express it in the internal language of the system. Semantic characterization of the text is impossible without the interpretation of the subject area, which in turn helps to reduce the ambiguity of natural language. A pragmatic analysis determines the appropriateness of the answer to a particular subject area.

To distinguish semantics from a natural-language text and to compare it with a model text in the developed system, we use a method of latent semantic analysis, which allows us to conclude on the basis of the correlation between words and texts the degree of closeness of the content of these words or groups of words. However, there are some limitations to the traditional method of latent semantic analysis: it does not take into account the order of words and, as a consequence, the method does not take into account syntactic relations, logic and morphology.

In view of this, the method of fuzzy semantic comparison of text responses of students submitted in electronic form with variants of correct answers in XML format was developed in the framework of the study. The developed algorithm is applied during the implementation of latent-semantic analysis at the stage of forming the frequency matrix of index words (terms) and provides the automated determination of lexical units of the text with the subsequent implementation of morphological, syntactic, semantic, and pragmatic analysis. The stemming procedure was replaced with the text unit lemmatization, that is, the procedure of reducing the formal variants of a word in the text to its definite invariant - lemma, or canonical (original, dictionary) word form. The source of the automatic lemmatizer action is the text, all words of which are assigned codes of grammar classes and subclasses. To compare fuzzy lexical units, it is suggested to use an improved Levenstein metric that allows you to set the degree of correspondence of the response text to the reference text from the subject domain database. To form an overall assessment of the text translation quality, a complex indicator is used, which takes into account the presence of the words in the model text (including in the case of inaccuracy), the correspondence of the structures of the sample and the evaluated text (word order) [6].

In the conceptual model of comparing textual information by content at the stages of semantic and pragmatic analysis, it is also proposed to use artificial intelligence models, in particular the neural network. The first layer of the neural network contains two groups of neurons. This layer contains the input information - the answer and the sample. Basic information processing is implemented in the following layers of neurons in which semantic text analysis is performed. The final result is used to obtain the validation result, which reflects the degree of identity of the two texts in content. The benefits of using a neural network are versatility. The neural network structure, which is unchanged, can be adapted to compare texts in different subject areas.

Thus, the conceptual model of the linguistic textual response system involves the application of the above algorithms, models, and methods for processing natural-language information, which allow to solve a number of actual linguistic problems, namely: 1) to identify latent associative-semantic dependencies in many documents; partially eliminate homonymy, polysemy and synonymy; 2) to correct words written with spelling and technical errors; 3) to take into account syntactic relationships; 4) to determine the relevance of the source text to a specific subject area; 5) to form an overall assessment of the text translation on the basis of a comprehensive indicator that takes into account the results of the described elements of the functional structure of the intellectual system of TQA.

Conclusion. The research conducted made it possible to accomplish analysis of the existing models of human translation quality automated evaluation system and suggest the innovative way of developing the new intellectual automated linguistic system of human translation quality assessment, based on conducting morphological, syntactical, semantic, and pragmatic text analysis, applying improved Levenstein distance metric, latent semantic analysis, and models of artificial intelligence.

\section{References:}

1. Balendr A., Komarnytska O., Bloshchynskyi I. (2019). Ukrainian border guards interoperability assessment in the framework of common European border guard standards implementation. Advanced Education, Vol. 6, Edition 12, pp. 35-43. doi: 10.20535/2410-8286.128196

2. Barhudarov L.S. (1975). Yazyk i perevod. Voprosy obshchey i chastnoi teorii perevoda [Language and translation. Problems of General and PartialTranslation Theory]. Moskva: Mezhdunar. otnosheniya.

3. Vasilieva I. Instrumenty avtomaticheskoi proverki kachestva perevoda QA. URL: https://translator-school.com/ $\mathrm{ru} /$ news/instrumenty-avtomaticheskoj-proverki-kachestva-perevoda-qa

4. House J. (2009). Translation. Oxford University Press, p. 53.

5. Kade O. (1978). Problemy perevoda v svete teorii kommunikatsii. Problemy perevoda v zarubezhnoi lingvistike [Translation problems within the communication theory. Transation problems in foreign linguistics]. Moskva: MGU.

6. Komarnitskaya O. (2014). Sovershenstvovanie algoritma latentno-semanticheskogo analiza nechetkoi tekstovoi informatsii. Souremennyi nauchnyi vestnik. № 29(225). Philological Sciences. Belgorod: Rusnauchkniga, pp. 58-62.

7. Komarnytska O., Vakoliuk T. (2013). Algorytm nechitkoho semantychnogo porivniannia tekstovoii informatsii. Zbirnyk naukovyh prats Viiskovoho instytutu Kyivskogo natsionalnogo universytetu imeni T. Shevchenko. Kyiv, no. 39 , pp. $163-168$.

8. Komarnytska O., Balendr A., Bloshchynskyi I. (2019). Esp Teaching Strategies of Ukrainian Border Guards Training on the Experince of European Union Countries. Journal of Teaching English for Specific and Academic Purposes. Pp. 455-465. https://doi.org/10.22190/JTESAP1803455K 
9. Komissarov V.N. (1973). Slovo o perevode [The word about translation]. Moskva: Mezhdunar. otnosheniya.

10. Marchuk Yu.N. (2007). Kompyuternaya lingvistika [Computer linguistics]. Moskva: Vostok-Zapad.

11. Shveytser A.D. (1988). Teoria perevoda: problem, aspekty [The theory of translation: problems and aspects]. Moskva: Nauka.

12. Williams, M. (2009). "Translation quality assessment," Mutatis Mutandis: Revista Latinoamericana de Traducción, vol. 2, no. 1, pp. 3-23.

13. XBench. URL: https://www.xbench.net

14. QA-distiller. URL: http://www.qa-distiller.com/en

15. E-verifika: https://e-verifika.com

\section{Список літератури:}

16. Balendr A., Komarnytska O., Bloshchynskyi I. (2019). Ukrainian border guards interoperability assessment in the framework of common European border guard standards implementation. Advanced Education, Vol. 6, Edition 12, pp. 35-43. doi: 10.20535/2410-8286.128196

17. Бархударов Л.С. Язык и перевод. Вопросы общей и частной теории перевода. Москва : Междунар. отношения, 1975. $238 \mathrm{c.}$

18. Васильева И. Инструменты автоматической проверки качества перевода QA. URL: https://translator-school.com/ $\mathrm{ru} /$ news/instrumenty-avtomaticheskoj-proverki-kachestva-perevoda-qa

19. House, J. (2009). Translation. Oxford University Press. P. 53.

20. Каде О. Проблемы перевода в свете теории коммуникации. Проблемы теории перевода в зарубежной лингвистике. Москва : МГУ, 1978. 473 с.

21. Комарницкая О.И. Совершенствование алгоритма латентно-семантического анализа нечеткой текстовой информации. Совреленный научный вестник. Серия : Филологические науки. Белгород : Руснаучкнига. 2014. № 29(225). C. 58-62.

22. Комарницька O.I., Ваколюк Т.В. Алгоритм нечіткого семантичного порівняння текстової інформації. Збірник наукових праць Військового інституту Київського національного університету іл. Т. Шевченка. Київ, 2013. № 39. С. 163-168.

23. Komarnytska O., Balendr A., Bloshchynskyi I. (2019). ESP Teaching Strategies Of Ukrainian Border Guards Training On The Experince Of European Union Countries. Journal of Teaching English for Specific and Academic Purposes. Pp. 455-465. https://doi.org/10.22190/JTESAP1803455K

24. Комиссаров В.Н. Слово о переводе. Москва : Международные отношения, 1973. 215 с.

25. Марчук Ю.Н. Компьютерная лингвистика : учеб. пособие. Москва : Восток-Запад, 2007. 319 с.

26. Швейцер А.Д. Теория перевода: проблемы, аспекты. М. : Наука, 1988. 214 с.

27. Williams, M. "Translation quality assessment," Mutatis Mutandis: Revista Latinoamericana de Traducción, vol. 2, no. 1, pp. 3-23, 2009.

28. XBench. URL: https://www.xbench.net

29. QA-distiller. URL: http://www.qa-distiller.com/en

30. E-verifika: https://e-verifika.com 